\title{
Thymineless Death in Bacillus subtilis
}

\author{
By R. N. BUICK* AND W. J. HARRIS \\ Department of Biochemistry, University of Aberdeen, Marischal College, \\ Aberdeen $A B 9$ I $A S$
}

(Received I8 October 1974; revised 20 December 1974)

SUMMARY

A study has been made of the intracellular changes occurring during thymineless death in Bacillus subtilis 2337. The kinetics of death were paralleled by the rate of breakdown of DNA. During thymineless death, single-strand breaks accumulated within DNA, breakdown of approximately $13 \%$ of the DNA to acid-soluble material occurred, deoxyribonuclease levels rose sharply, and yet double-strand breaks did not occur in the DNA. On restoration of thymine, however, doublestrand breaks accumulated, though this could be prevented by the specific inhibition of DNA replication on restoration of thymine. The results probably indicate that during thymineless death, single-strand gaps accumulate within the DNA of cells. On restoration of thymine both DNA replication and repair of gaps are simultaneously initiated, and when a replication fork reaches a gap before it is repaired, double-strand breakage of the DNA occurs. The possible relevance of these events to the lethality of the cells is discussed.

\section{INTRODUCTION}

The ultimate effect of thymine starvation of bacterial strains which require thymine for growth, is death of the starved cells. This phenomenon is termed thymineless death and has been demonstrated in many bacterial species. Thymine starvation has several biological effects, all of which could be related to, or responsible for cell death: mutagenesis (Coughlin \& Adelberg, I956), prophage induction (Melechen \& Skaar, 1962), DNA damage (Mennigman \& Szybalski, I962), premature initiation of replication (Pritchard \& Lark, 1964), and abnormal cell elongation (Cummings \& Mondale, 1967). Despite extensive study, it has proved impossible to correlate cell death with any one of these effects, suggesting the lethal process to be a composite of some or all of these processes. There is, however, circumstantial evidence to suggest that damage to DNA is an important factor in the lethal process. Singlestrand breaks have been reported to occur during thymineless death in several strains of Escherichia coli (Mennigman \& Szybalski, 1962; Friefelder, 1969; Walker, 1970; Reichenbach, Schaiberger \& Sallman, 197I), but have not been detected in E. coli C32 I (Baker \& Hewitt, 1971) or in E. coli w3110 (Sedgwick \& Bridges, 1971). This suggests that no single cause of thymineless death is likely to be universally applicable, and that different bacterial species, and different strains of the same species, undergo death due to a composite of the various processes discussed above.

In the present research, the nature of thymineless death in a strain of Bacillus subtilis has been examined in an attempt to correlate changes in DNA with the loss of cell viability.

* Present address: McArdle Laboratory for Cancer Research, University of Wisconsin, Madison, Wisconsin, U.S.A. 


\section{METHODS}

Materials. $\left[6-{ }^{3} \mathrm{H}\right]$ thymidine (approx. ${ }_{15} \mathrm{Ci} / \mathrm{mmol}$ ) and $\left[6-{ }^{3} \mathrm{H}\right]$ thymine (approx. $20 \mathrm{Ci} / \mathrm{mmol}$ ) were obtained from the Radiochemical Centre, Amersham, Buckinghamshire; endonuclease (from Neurospora crassa, single-strand specific) was from Boehringer Corp., London; 6-p-hydroxyphenyl-azo uracil (HOPhNNUra) was generously given by $\mathrm{Dr} \mathrm{B}$. W. Langley, I.C.I. Ltd, Alderley Park, Cheshire.

Growth of bacteria. The bacterial strain used throughout this work was B. subtilis 2337 (thy met ilva) and was obtained from Dr J. Gross. Bacteria were maintained on tryptose blood agar base (Oxoid) and inoculated into $5 \mathrm{ml}$ batches of growth medium in $25 \times 150 \mathrm{~mm}$ test tubes. The bacteria were shaken at $37^{\circ} \mathrm{C}$ for 14 to $17 \mathrm{~h}$, and $0.5 \mathrm{ml}$ of this stationary phase culture transferred to $4.5 \mathrm{ml}$ of fresh medium and incubated for a further $3 \mathrm{~h}$. At this time the organisms were in mid-exponential phase at a concentration of $4 \times 10^{8} / \mathrm{ml}$. The growth medium employed was the minimal medium described by Kelly \& Pritchard (1965), supplemented with $0.02 \%(\mathrm{w} / \mathrm{v})$ casein hydrolysate and $5 \mu \mathrm{g}$ thymine $/ \mathrm{ml}$.

Bacteria in mid-exponential phase were washed free of thymine by filtration using nitrocellulose membrane filters. A I ml portion of the culture was washed with $4 \times 10 \mathrm{ml}$ ice-cold minimal medium and then resuspended in pre-warmed medium lacking thymine. Incubation of bacteria in the absence of thymine was carried out under the same conditions as described above. Growth was monitored by EEL nephelometer measurements, and viable counts determined by plating on tryptose blood agar base.

Incorporation of radioactive precursors into bacteria. Bacteria were grown as described, with $\left[6-{ }^{3} \mathrm{H}\right]$ thymidine $(0.5 \mu \mathrm{Ci} / \mathrm{ml})$ added to the overnight liquid culture and $\left[6-{ }^{3} \mathrm{H}\right]$ thymidine ( $5 \mu \mathrm{Ci} / \mathrm{ml})$ added during growth to mid-exponential phase. In these growth media, the concentration of thymine was reduced to $2 \mu \mathrm{g} / \mathrm{ml}$.

Preparation of cell lysates. Five $\mathrm{ml}$ volumes of culture were washed with ice-cold $0 . \mathrm{I} \mathrm{M}$ $\mathrm{NaCl}-0.0 \mathrm{I}$ M-EDTA, $\mathrm{pH} 8.0(2 \times \mathrm{I} 0 \mathrm{ml})$ by filtration through a nitrocellulose filter. The cells were then resuspended in $0.5 \mathrm{ml}$ minimal medium containing $5 \%(\mathrm{w} / \mathrm{v})$ sucrose, and lysozyme was added to $\mathrm{I} 50 \mu \mathrm{g} / \mathrm{ml}$. The suspension was incubated at $37^{\circ} \mathrm{C}$ for I $5 \mathrm{~min}$. Before analysis in alkaline sucrose gradients, the lysate was made $0^{\circ} \mathrm{I} M$ with respect to $\mathrm{NaOH}$, allowed to stand on ice for $15 \mathrm{~min}$, and then carefully applied to the surface of the gradient by means of a wide-bore pipette. Centrifugation was performed immediately. For neutral sucrose gradients, protease (DNAase-free) was added to the lysozyme-treated suspension to a final concentration of $200 \mu \mathrm{g} / \mathrm{ml}$. The suspension was then layered on to the surface of a 5 to $20 \%(\mathrm{w} / \mathrm{v})$ linear sucrose gradient $\mathrm{pH} 8 \cdot 0$, and allowed to stand overnight at $4{ }^{\circ} \mathrm{C}$ before centrifugation.

Zone centrifugation through sucrose gradients was performed by preparing $5 \mathrm{ml}$ of 5 to $20 \%(\mathrm{w} / \mathrm{v})$ linear sucrose gradients at $\mathrm{pH} 8.0$ or $\mathrm{I} 2.0$ as previously described (Harris \& Barr, 1969) and centrifuging in an M.S.E. Superspeed 65 ultracentrifuge in a $3 \times 5 \mathrm{ml}$ swing-out rotor (M.S.E. design No. 59589) at $100000 \mathrm{~g}$ for $90 \mathrm{~min}$ at $5{ }^{\circ} \mathrm{C}$ (average radius $6.4 \mathrm{~cm}$ ). Six-drop fractions were collected, by upward displacement of the gradient, directly on glass-fibre filter discs. DNA, as substrate for $N$. crassa endonuclease, was prepared by centrifugation of lysates in 15 to $30 \%$ sucrose gradients, $\mathrm{pH} 8 \cdot 0$. Values for $s_{20 \text {, w }}$ were calculated from the formula derived by Abelson \& Thomas (1966), and molecular weights estimated with the empirical relationships described by Studier (1965).

Preparation of enzyme extracts. Cells were harvested and washed twice at $4{ }^{\circ} \mathrm{C}$ with buffer (0.02 M-tris- $\mathrm{HCl} \mathrm{pH} \mathrm{8.5,} \mathrm{0.00I} \mathrm{M-} \mathrm{MgCl}_{2}, 0.002 \mathrm{M}$-EDTA, 0.00I M-2-mercaptoethanol). The bacteria were resuspended in buffer ( I g wet wt cells $/ 8 \mathrm{ml}$ ), lysozyme was added to $\mathrm{I} 50 \mu \mathrm{g} / \mathrm{ml}$, 
and the cells were incubated at $37^{\circ} \mathrm{C}$ for $15 \mathrm{~min}$. High-speed supernatant cell extracts were obtained by centrifugation in an M.S.E. IO $\times 10 \mathrm{ml}$ fixed-angle rotor (aluminium standard angle rotor with angle of tube to axis of $20^{\circ}$ ) in an M.S.E. Superspeed 65 ultracentrifuge for $\mathrm{I} \mathrm{h}$ at $4{ }^{\circ} \mathrm{C}$ and $100000 \mathrm{~g}$ (average radius $6.0 \mathrm{~cm}$ ).

Assay of deoxyribonuclease activity. Deoxyribonuclease assays were performed by measuring the degradation of radioactively labelled DNA to TCA-soluble material. DNA was prepared from B. subtilis grown in the presence of $\left[6-{ }^{3} \mathrm{H}\right]$ thymidine $(\mathrm{I} 00 \mu \mathrm{Ci} / \mathrm{ml})$ as described above, and denatured by heating at $100{ }^{\circ} \mathrm{C}$ for $10 \mathrm{~min}$ and cooling rapidly. Denatured DNA $\left(0.5 \mu \mathrm{g}\right.$; specific activity $2 \times 10^{4}$ c.p.m. $\left./ \mu \mathrm{g}\right)$ was added to $0.25 \mathrm{ml}$ assay mixture containing $0.04 \mathrm{M}$-tris- $\mathrm{HCl} \mathrm{pH} 7.5,0.002 \mathrm{M}-\mathrm{CaCl}_{2}$, and $50 \mu \mathrm{g}$ bovine serum albumin. Incubation was carried out for $30 \mathrm{~min}$ at $37^{\circ} \mathrm{C}$ and the reaction stopped by the addition of $250 \mu \mathrm{g}$ calf-thymus DNA and ice-cold trichloroacetic acid to $5 \%(\mathrm{w} / \mathrm{v})$. After standing in ice for $30 \mathrm{~min}$, samples were centrifuged at $2700 \mathrm{~g}$ at $4{ }^{\circ} \mathrm{C}$ for $20 \mathrm{~min}$, and $\mathrm{O} . \mathrm{I} \mathrm{ml} \mathrm{portions}$ counted in $10 \mathrm{ml}$ aqueous scintillation fluid.

Radioactivity measurements. Glass-fibre filters (type GF/C) were placed in ice-cold $10 \%$ $(\mathrm{w} / \mathrm{v})$ TCA for $10 \mathrm{~min}$, and washed once in $0.5 \mathrm{M}-\mathrm{HCl}$ and twice in ethanol before being dried at $70{ }^{\circ} \mathrm{C}$ for $\mathrm{I} h$. They were then placed in $2 \mathrm{ml}$ of non-aqueous scintillation fluid containing $5 \mathrm{~g}$ 2,5-diphenyloxazole and $0.3 \mathrm{~g}$ I,4-bis-(5-phenyloxazol-2-yl)benzene per $\mathrm{I}$ toluene. Aqueous scintillation fluid contained $0.05 \mathrm{~g} \mathrm{I}, 4$-bis-(5-phenyloxazol-2-yl)benzene, $5 \mathrm{~g} \mathrm{2,5}$-diphenyloxazole and $80 \mathrm{~g}$ naphthalene in $385 \mathrm{ml}$ dioxan, $385 \mathrm{ml}$ toluene and $230 \mathrm{ml}$ ethanol. Radioactivity measurements were carried out in a Packard liquid scintillation spectrometer.

TCA-soluble radioactivity was measured by removing duplicate portions $(0.5 \mathrm{ml})$ from cultures and adding TCA to $5 \%(\mathrm{w} / \mathrm{v})$. One sample was heated to $90{ }^{\circ} \mathrm{C}$ for $20 \mathrm{~min}$. After $30 \mathrm{~min}$ in ice, both samples were centrifuged at $2700 \mathrm{~g}$ for $20 \mathrm{~min}$ (average radius $18 \mathrm{~cm}$ ). The supernatants were removed and extracted 4 times with ether. Portions $(0 \cdot 2 \mathrm{ml})$ of the residue were then counted in $\mathrm{Io} \mathrm{ml}$ aqueous scintillation fluid.

\section{RESULTS}

\section{General characteristics of thymineless death}

Figure I demonstrates that exponentially growing cells of $B$. subtilis 2337, when grown in medium lacking thymine, undergo thymineless death in a manner similar to other thyminerequiring strains (Cohen \& Barner, I954; Hanawalt \& Maaloe, 196I). Bacteria resuspended at a concentration of $10^{6}$ organisms $/ \mathrm{ml}$ in medium lacking thymine undergo exponential death after a lag of approximately $\mathrm{I} h$. It was found that different kinetics of death were obtained, depending on the initial cell concentration at the time of thymine deprivation (unpublished results). Since optimum death occurred at a cell concentration of $10^{6}$ organisms/ $\mathrm{ml}$, this concentration was used in all subsequent studies.

Organisms which had been radioactively labelled in their DNA for several generations released approximately $13 \%$ of their radioactivity as acid-soluble material during $4 \mathrm{~h}$ of thymine starvation (Fig. I). Also, the kinetics of this breakdown correlated with the loss of cell viability, both showing a lag of approximately $\mathrm{I} h$. That this is likely to be a specific breakdown of DNA, rather than caused by lysis of a few cells within the population, was shown by simultaneously measuring the breakdown of previously labelled protein. Since this strain of $B$. subtilis secretes protease during vegetative growth (unpublished results), a large fraction of protein released into the medium is degraded. No breakdown of protein was detectable during $4 \mathrm{~h}$ of thymine starvation (results not presented). 


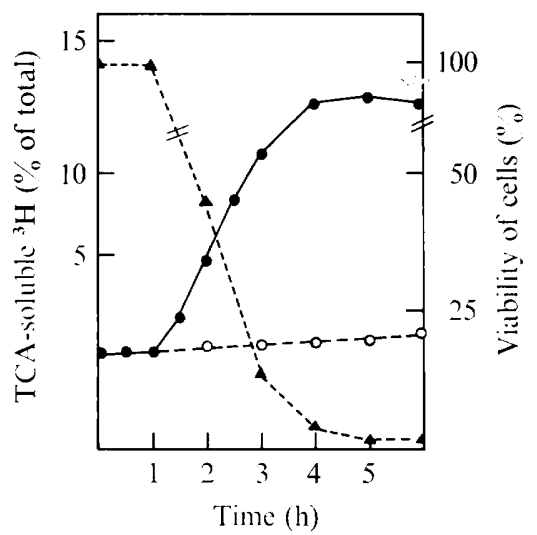

Fig. I. Degradation of DNA during incubation of bacteria in the absence of thymine. Cells $(5 \mathrm{ml})$, pre-grown in medium containing $\left[6-{ }^{3} \mathrm{H}\right]$ thymidine, were subjected to thymine deprivation. The radioactivity soluble in $5 \%(\mathrm{w} / \mathrm{v})$ TCA was measured as described in Methods. The results are expressed as a percentage of the total radioactivity in the culture at the time of analysis of the sample. $\boldsymbol{\Delta}$, Viability of cells; $\boldsymbol{O}$, TCA-soluble radioactivity accumulated during thymine deprivation; $\mathrm{O}$, TCA-soluble radioactivity accumulated in a fully-supplemented medium.

\section{Sucrose gradient analysis of DNA from organisms grown in medium lacking thymine}

The molecular weight of DNA extracted from bacteria incubated in the absence of thymine was examined by centrifugation through neutral sucrose gradients (Fig. 2). It can be seen that no reduction in double-strand molecular weight can be detected during $4 \mathrm{~h}$. All samples displayed a sedimentation value of $69 \mathrm{~S}$, equivalent to a molecular weight of $2 \cdot 3 \times 10^{8}$ daltons (Studier, 1965 ). At $\mathrm{pH} 12 \cdot 0$, however, it can be seen that there was a gradual decrease in the single-strand molecular weight (Fig. 2). While the control sample had a sedimentation of $57 \mathrm{~S}\left(3.9 \times 10^{7}\right.$ daltons), the corresponding values after 2 and $4 \mathrm{~h}$ of thymineless death can be calculated as $4 \mathrm{I} S\left(\mathrm{I} \cdot 7 \times 10^{7}\right.$ daltons $)$ and $23 \mathrm{~S}\left(3.9 \times 10^{6}\right.$ daltons $)$.

\section{Susceptibility of DNA to single-strand specific endonuclease}

Neurospora crassa endonuclease is single-strand specific (Linn \& Lehman, 1965), and the susceptibility of DNA extracted from cells incubated in medium lacking thymine to this enzyme is illustrated by Fig. 3. Native DNA was isolated from cells grown $4 \mathrm{~h}$ in fully supplemented and thymineless media, by centrifugation of cell lysates in 15 to $30 \%$ sucrose gradients. It can be seen that the rate of sedimentation of DNA extracted from cells incubated in medium lacking thymine is reduced in neutral sucrose gradients by treatment with this enzyme. This strongly suggests that such DNA possesses internal single-strand gaps.

\section{Effect of re-addition of thymine to starved bacteria}

Thymine was restored at various times to cells grown in medium lacking thymine, and it can be seen (Fig. 4) that recovery of viability in liquid culture could be effected during the first $2 \mathrm{~h}$ of thymine deprivation. The restoration of thymine had no effect on the increase in turbidity of the culture, suggesting that restoration of thymine did not cause lysis of the cells. This latter observation argues against the involvement of prophage induction in the lethal event with this strain.

Figure 5 shows the effect of restoration of thymine on the sedimentation of extracted DNA in neutral sucrose gradients. While no double-strand breaks were introduced during in- 


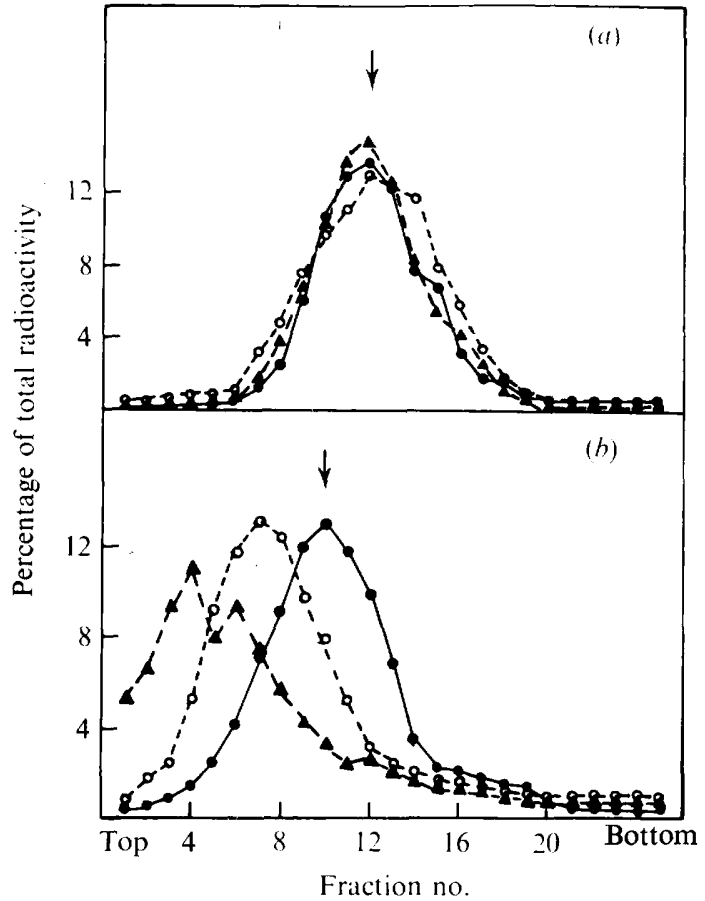

Fig. 2

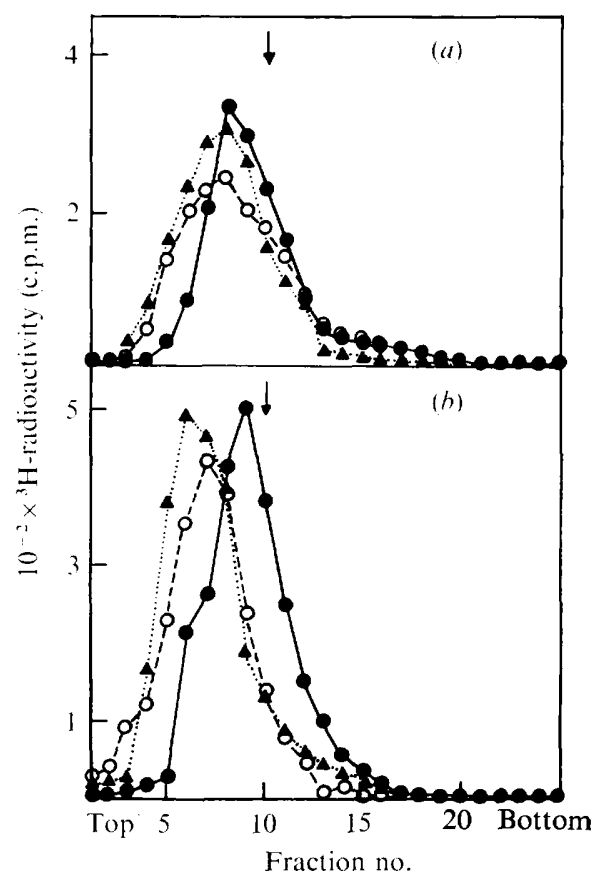

Fig. 3

Fig. 2. Sucrose-gradient analysis of DNA from cells incubated in the absence of thymine. Samples of cells $(5 \mathrm{ml})$ were subjected to thymine deprivation, and lysates analysed in 5 to $20 \%(\mathrm{w} / \mathrm{v})$ sucrose gradients at $(a) \mathrm{pH} 8.0$ and $(b) \mathrm{pH} 12.0$. Centrifugation was performed for $90 \mathrm{~min}$ at $100000 \mathrm{~g}$ at $4{ }^{\circ} \mathrm{C}$. DNA from lysates of cells grown to mid-exponential phase in medium containing $\left[2-{ }^{14} \mathrm{C}\right]-$ thymine $(0.1 \mu \mathrm{Ci} / \mathrm{ml})$ was used as marker, and is indicated by the arrows. Results are expressed as the percentage of total radioactivity recovered from each gradient. $\boldsymbol{O}$, Control cells ( $4 \mathrm{~h}$ growth in fully-supplemented medium); $\bigcirc$, cells grown $2 \mathrm{~h}$ in the absence of thymine; $\boldsymbol{\Delta}$, cells grown $4 \mathrm{~h}$ in the absence of thymine.

Fig. 3. Susceptibility of DNA to $N$. crassa endonuclease. Portions of DNA, purified as described in the text, were treated with $N$. crassa endonuclease; the assay contained $0 \cdot \mathrm{I} \mathrm{M}$-tris- $\mathrm{HCl} \mathrm{pH} 7 \cdot 5$, $0.0 \mathrm{I} \mathrm{M}-\mathrm{MgCl}_{2}$, and $50 \mathrm{ng}$ of enzyme diluted in $0.5 \mathrm{M}$-tris- $\mathrm{HCl} \mathrm{pH} 7.5$. Incubation was carried out at $37^{\circ} \mathrm{C}$ and the reaction stopped by the addition of EDTA to $0.05 \mathrm{M}$. Portions $(0.2 \mathrm{ml})$ of assays were then re-analysed within 15 to $30 \%$ sucrose gradients, $\mathrm{pH} 8 \%$. All radioactivity measured was precipitable with $5 \%$ TCA. The arrows mark the positions of marker $E$. coli DNA included in all gradients. (a) Control DNA: $\bigcirc$, untreated; $\bigcirc, 5$ min contact with enzyme; $\boldsymbol{\Delta}$, I 5 min contact with enzyme. (b) Thymineless death DNA: $\boldsymbol{O}$, untreated; 0,5 min contact with enzyme; $\boldsymbol{\Delta}, 15 \mathrm{~min}$ contact with enzyme.

cubation in thymineless medium (Fig. 2), restoration of thymine caused the accumulation of double-strand breaks within the DNA (Fig. 5). The effect of HOPhNNUra on the accumulation of these double-strand breaks is shown in Fig. $5(b)$, from which it can be seen that HOPhNNUra, a specific inhibitor of DNA replication (Brown, I971), prevents the formation of double-strand breaks. 


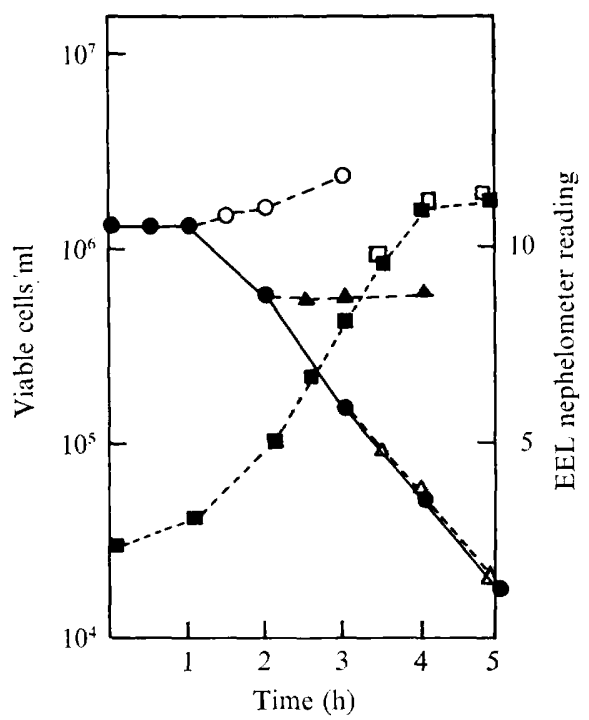

Fig. 4

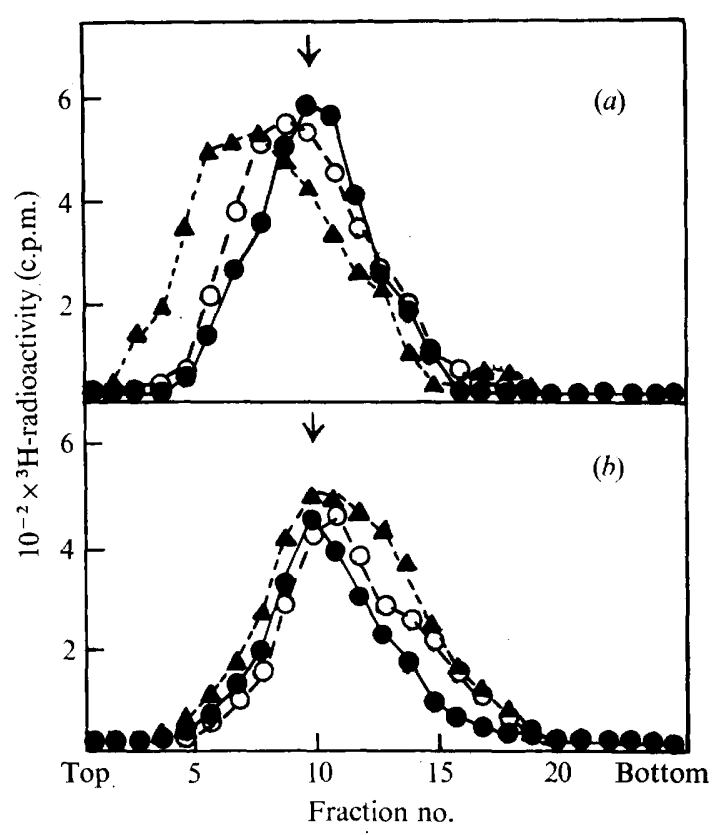

Fig. 5

Fig. 4. Effect of re-addition of thymine upon cell viability in liquid culture of cells incubated in the absence of thymine. Bacteria, grown for various periods of time in the absence of thymine, had thymine restored to the liquid culture $(10 \mu \mathrm{g} / \mathrm{ml})$, and samples of cells were subsequently plated on tryptose blood agar at the times indicated. Thymine was restored: $\bullet$, never; $\bigcirc$, after $\mathrm{I} \mathrm{h}$ of starvation; $\Delta, 2 \mathrm{~h}$ starvation; $\triangle, 3 \mathrm{~h}$ starvation. $\mathbf{\square}$, Increase in cell mass, as determined in the EEL nephelometer; $\square$, increase in cell mass on restoration of thymine after $3 \mathrm{~h}$ thymine deprivation.

Fig. 5. Effect of re-addition of thymine on the sedimentation profile of DNA from cells incubated in the absence of thymine. (a) After $2 \mathrm{~h}$ of thymine starvation, thymine (10 $\mu \mathrm{g} / \mathrm{ml})$ was restored

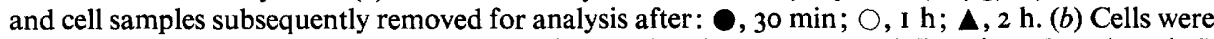
treated as described for (a) but at the same time as thymine was restored, HOPhNNUra (I $\mu \mathrm{g} / \mathrm{ml}$ ) was added and the cells incubated for a further $0,30 \mathrm{~min} ; \mathrm{O}, \mathrm{I} \mathrm{h;} \boldsymbol{\Delta}, 2 \mathrm{~h}$. Samples were analysed in 5 to $20 \%$ sucrose gradients, $\mathrm{pH} 8.0$ by centrifugation at $100000 \mathrm{~g}$ at $4{ }^{\circ} \mathrm{C}$ for $90 \mathrm{~min}$, as described for Fig. 2.

\section{Table I. Effect of thymine starvation on deoxyribonuclease levels}

Cells $(250 \mathrm{ml})$ in mid-exponential phase of growth were subjected to thymineless death at an initial cell concentration of $10^{8}$ cells $/ \mathrm{ml}$. Fifty $\mathrm{ml}$ of cells were removed thereafter and enzyme extracts prepared as described in Methods. The DNAase activity, using denatured DNA as substrate, was assayed as described in Methods.

Time of preparation of extract (h)

$0 \quad 1 \cdot 0$

$2 \cdot 5$

$3 \cdot 5$

$\begin{array}{llllll}\text { Specific activity of DNAase (ng DNA hydrolysed/mg protein) } & \text { II } \cdot 8 & 8.6 & 59.5 & 103.2 & \text { I09.8 }\end{array}$

\section{Levels of exonuclease within cells during growth in medium lacking thymine}

Since the preceding findings indicated breakdown of DNA, the levels of single-strand specific exonuclease within such cells were examined and an example is shown in Table I. It can be seen that the specific activity of $\mathrm{Ca}^{2+}$-dependent, single-strand specific, exonuclease increased ninefold during $4 \mathrm{~h}$ of thymine starvation. Moreover, the timing of increase in activity correlates with the onset of exponential death of the cells (Fig. I), and with the increase in breakdown of the DNA. 


\section{DISCUSSION}

Figure I demonstrates that approximately $13 \%$ of the total DNA of bacteria is rendered acid-soluble during $4 \mathrm{~h}$ of thymine deprivation. Furthermore, the kinetics of this release correlates well with the kinetics of death of the cells (Fig. I) and with the increase in specific activity of exonuclease (Table I). Also, examination of the DNA within alkaline sucrose gradients clearly demonstrates single-strand breaks to accumulate (Fig. 2). Assuming a molecular weight of $2 \times 10^{9}$ daltons for the entire genome of $B$. subtilis (Dennis \& Wake, 1966), it is possible to calculate the number of single-strand breaks per chromosome from the data of Fig. 2. The DNA in the control had approximately 50 single-strand breaks per chromosome; after $2 \mathrm{~h}$ of thymine deprivation there were I 20 breaks per chromosome, rising to 540 breaks after $4 \mathrm{~h}$. Incubation of cells for $4 \mathrm{~h}$ in fully supplemented medium caused no increase in the number of single-strand breaks (results not presented). This is consistent with a rate of production of breaks during thymine deprivation of $0.6 / \mathrm{min} /$ chromosome during the first $2 \mathrm{~h}$, and $3.5 / \mathrm{min} /$ chromosome for the period 2 to $4 \mathrm{~h}$. Similar rates calculated from the data for E. coli by Walker (1970) and Friefelder (I969) were 0.2 I and $0.98 \mathrm{breaks} / \mathrm{min} /$ chromosome, respectively.

Despite this number of single-strand breaks, no double-strand breaks accumulated (Fig. 2). After re-addition of thymine to starved cells, however, it was found impossible to recover DNA from cells with the same sedimentation rate through neutral sucrose, suggesting that double-strand breakage of the DNA occurred within the cells. This is supported by the fact that this breakage did not occur if DNA replication was inhibited by HOPhNNUra at the time of restoration of thymine.

In summary, the evidence presented is most consistent with the concept that during thymineless death, single-strand breaks accumulate within the chromosomes. Such breaks are extended into gaps by the increase in exonuclease activities. On restoration of thymine, both DNA replication and repair of these gaps is initiated. However, if the replication fork reaches a gap before it is repaired, shearing of the chromosome occurs. Pauling \& Hanawalt (I965) have demonstrated the occurrence of non-conservative DNA synthesis on restoration of thymine to cells subjected to thymine deprivation.

It is tempting to suggest that the proposed cleavage of chromosomes as a result of restoration of DNA replication is the lethal event during thymineless death (Harris, I973; Little \& Hanawalt, 1973). However, such a conclusion would be premature. There is evidence for a role for extracellular factors (Buick \& Harris, 1972), and aberrant methylation (Buick \& Harris, 1973). The observed thymineless death would not seem to be an increased sensitivity to plating as has been observed in E. coli (Cummings \& Kusy, 1969; Donachie \& Hobbs, 1967), since viability after $2 \mathrm{~h}$ of thymine starvation could not be restored by incubation in liquid medium (Fig. 4). In several strains, prophage induction has been proposed as the lethal event (Mennigman, 1964). This would not seem to be the case for the present strain since no cell lysis was observed on restoration of thymine (Fig. 4), nor could any phage particles be detected by electron-microscopic examination of lysates from cells which had undergone thymineless death.

We acknowledge the excellent technical assistance of Miss Laura Fraser, and the financial support of the Medical Research Council. 


\section{REFERENCES}

Abelson, J. \& Thomas, C. A. (1966). The anatomy of the T5 bacteriophage DNA molecule. Journal of Molecular Biology I8, 262-29I.

BAKER, M. L. \& HEWITT, R. R. (197I). Influence of thymine starvation on the integrity of DNA in E. coli. Journal of Bacteriology ro5, 733-738.

BRown, N. C. (197I). Inhibition of bacterial DNA replication by 6-( $p$-hydroxyphenylazo)-uracil; differential effect on repair and semi-conservative synthesis in Bacillus subtilis. Journal of Molecular Biology 59, I-I 6.

Buick, R. N. \& HARRIS, W. J. (I972). A factor responsible for thymineless death in Bacillus subtilis. Biochemical Journal 129, 49P.

BUICK, R. N. \& HARRIS, W. J. (1973). Methylation of DNA under conditions of thymine deprivation in Bacillus subtilis. In Abstracts of the 9th International Congress of Biochemistry, p. I87.

Cohen, S. S. \& Barner, H. D. (1954). Studies on unbalanced growth in E. coli. Proceedings of the National Academy of Sciences of the United States of America 4o, 885-893.

Coughlin, C. A. \& Adelberg, E. A. (1956). Bacterial mutation induced by thymine starvation. Nature, London 178, $53 \mathrm{I}-532$.

Cummings, D. J. \& KusY, A. R. (1969). Thymineless death in E. coli: inactivation and recovery. Journal of Bacteriology 99, 558-566.

Cummings, D. J. \& MondaLE, L. (1967). Thymineless death in E. coli: strain specificity. Journal of Bacteriology 93, $1917-1924$.

DENNIS, E. S. \& WAKE, R. G. (1966). Autoradiography of the B. subtilis chromosome. Journal of Molecular Biology 15, 435-439.

DonachiE, W. D. \& HobBs, D. J. (1967). Recovery from thymineless death in E. coli. Biochemical and Biophysical Research Communications 29, I72-177.

FRIEFELDER, D. (1969). Single-strand breaks in bacterial DNA associated with thymine starvation. Journal of Molecular Biology 45, I-7.

Hanawalt, P. \& MaAloe, O. E. (I96I). Thymine deficiency and the normal DNA replication cycle. Journal of Molecular Biology 3, I44-155.

HARRIS, W. J. \& BARR, G. C. (1969). Some properties of DNA in competent Bacillus subtilis. Journal of Molecular Biology 39, 245-255.

HARRIS, W. J. (1973). Possible roles of the enzymes of recombination and repair of DNA during normal growth. Biochemical Society Transactions r, 240-244.

Kelly, T. J. \& PritchaRd, R. H. (I965). Unstable linkage between genetic markers in transformation. Journal of Bacteriology 89, 1 314-132I.

LinN, S. \& Lehman, I. R. (1965). An endonuclease from Neurospora crassa specific for polynucleotides lacking an ordered structure. Journal of Biological Chemistry 240, I 289-I 304.

Little, J. G. \& Hanawalt, P. C. (1973). Thymineless death and u.v.-sensitivity in Micrococcus radiodurans. Journal of Bacteriology I13, 233-240.

Melechen, N. E. \& SkaAR, P. P. (I962). The provocation of an early step of induction by thymine deprivation. Virology 16, $2 \mathrm{I}-29$.

MenNIGMAN, H. D. (1964). Induction in Escherichia coli 15 of the colicinogenic factor by thymineless death. Biochemical and Biophysical Research Communications 16, 373-378.

Mennigman, H. D. \& SzYBALSKI, W. (1962). Molecular mechanism of thymineless death: Biochemical and Biophysical Research Communications 9, 398-404.

Pauling, C. \& Hanawalt, P. (1965). Non-conservative DNA replication in bacteria after thymine starvation. Proceedings of the National Academy of Sciences of the United States of America 54, 1728-1 735.

PRITCHARD, R. H. \& LARK, K. G. (1964). Induction of replication by thymine starvation. Journal of Molecular Biology 9, 288-307.

Reichenbach, D. L., Schaiberger, G. E. \& Sallman, B. (1971). Effect of thymine starvation on chromosomal structure of E. coli JG-I 5I. Biochemical and Biophysical Research Communications 42, 23-30.

SEDGWICK, S. G. \& BRIDGES, B. A. (I97I). Alkaline sucrose gradient sedimentation of chromosomal DNA from E. coli POLA $^{+}$and POLA ${ }^{-}$strains during thymine starvation. Journal of Bacteriology 108, 1422I423.

STUDIER, F. W. (1965). Sedimentation studies of the size and shape of DNA. Journal of Molecular Biology II, 373-390.

WaLKER, J. R. (1970). Thymine starvation and single-strand breaks in chromosomal DNA from E. coli. Journal of Bacteriology I04, I391-1 392. 